\title{
Penerapan Model Pembelajaran Discovery Learning untuk Meningkatkan Hasil Belajar Materi Operasi Bentuk Aljabar pada Siswa Kelas X Akuntansi-2 SMK Negeri I Waingapu
}

\begin{tabular}{|c|c|}
\hline & $\begin{array}{c}\text { Letu Paulus }{ }^{1 *} \\
{ }^{1} \text { SMK Negeri I Waingapu } \\
\text { Jl. Jenderal Soeharto, Kel. Hambala, Kecamatan Kota Waingapu, NTT } \\
{ }^{*} \text { Corresponding Author: letu_paulus@gmail.com }\end{array}$ \\
\hline Info Artikel & Abstract \\
\hline $\begin{array}{l}\text { Sejarah Artikel: } \\
\text { Diterima } 11 / 01 / 2020 \\
\text { Direvisi } 19 / 02 / 2020 \\
\text { Disetujui } 18 / 03 / 2020\end{array}$ & $\begin{array}{l}\text { The purpose of this research is to: (1) Improve the learning outcomes of algebraic operation } \\
\text { material in grade X students Accounting-2 SMK Negeri I Waingapu in 2018/2019 by } \\
\text { implementing the Discovery learning model. (2) To increase the activity of learning } \\
\text { Mathematics of algebraic operations in grade X students in Accounting-2 SMK Negeri I } \\
\text { Waingapu by implementing the Discovery learning model. This research is a collaborative }\end{array}$ \\
\hline $\begin{array}{lr}\text { Keywords: } & \text { students } \\
\text { achievments, } & \text { discovery } \\
\text { learning, } \quad \text { learning } \\
\text { outcomes }\end{array}$ & $\begin{array}{l}\text { classroom action (CAR) study implemented in two cycles. The subject in this study was the } \\
\text { grade X student Accounting-2 SMK Negeri I Waingapu in 2018/2019 with a total of } 36 \\
\text { people. Each cycle consists of two meetings. The data collection techniques used in this study } \\
\text { were observations, tests and documentation. The instruments used are observation sheets } \\
\text { and tests. Analysis of the data used is the analysis of the implementation of learning, learning } \\
\text { outcomes and success criteria. The defined success indicator is when the average class } \\
\text { increases from the preset, cycle I and cycle II. The results showed that students } \\
\text { mathematical learning results were improved. This is evidenced by the increased percentage } \\
\text { of the classical, which is from the preview 31\%, Cycle I } 69 \% \text { and cycle II 94\%. In addition to } \\
\text { the observation data obtained before the action, students look less active in learning } \\
\text { activities, learning activities are more dominated by teachers. After being given an action, } \\
\text { students appear active during a learning activity and at the time of the group discussion. }\end{array}$ \\
\hline
\end{tabular}

Abstrak

Tujuan penelitian ini adalah untuk: (1) Meningkatkan hasil belajar materi operasi bentuk aljabar pada siswa kelas X Akuntansi-2 SMK Negeri I Waingapu tahun 2018/2019 dengan menerapkan model pembelajaran discovery learning. (2) Meningkatkan aktivitas belajar matematika materi operasi bentuk aljabar pada siswa kelas X Akuntansi-2 SMK Negeri I Waingapu dengan menerapkan model pembelajaran discovery learning. Jenis penelitian ini adalah penelitian tindakan kelas (PTK) kolaboratif yang dilaksanakan dalam dua siklus. Subjek dalam penelitian ini yaitu siswa kelas X Akuntansi-2 SMK Negeri I Waingapu tahun pelajaran 2018/2019 dengan jumlah 36 orang. Setiap siklus terdiri dari dua pertemuan. Teknik pengumpulan data yang digunakan dalam penelitian ini yaitu observasi, tes dan dokumentasi. Instrument yang digunakan adalah lembar observasi dan soal tes. Analisis data yang digunakan adalah analisis keterlaksanaan pembelajaran, hasil belajar dan kriteria keberhasilan. Indikator keberhasilan yang ditetapkan apabila rata-rata kelas meningkat dari pratindakan, siklus I dan siklus II. Hasil penelitian ini menunjukan bahwa hasil belajar matematika siswa mengalami peningkatan. Hal ini terbukti dengan adanya peningkatan persentase ketuntasan klasikal yaitu pratindakan $31 \%$, siklus I $69 \%$ dan siklus II $94 \%$. Selain itu dari data observasi diperoleh sebelum diberikan tindakan siswa terlihat kurang aktif dalam kegiatan pembelajaran, kegiatan pembelajaran lebih didominasi oleh guru. Setelah diberikan tindakan siswa terlihat aktif pada saat kegiatan pembelajaran dan pada saat diskusi kelompok.

\footnotetext{
*Alamat korespondensi:

J1. Jenderal Soeharto, Kel. Hambala, Kecamatan Kota

Waingapu, Kabupaten Sumba Timur.

E-mail: letu_paulus@gmail.com
}

(C) 2020 Program Studi PGSD Universitas Flores Email: primagistrauniflor@gmail.com 


\section{PENDAHULUAN}

Pendidikan adalah salah satu hal yang terpenting dalam kehidupan manusia, karena melalui pendidikan akan dapat menciptakan manusia berpotensi, kreatif dan memiliki ide cemerlang sebagai bekal untuk memperoleh masa depan yang baik. Sesuai yang termuat dalam Undang-undang No 20 Tahun 2003 Pasal 1 Ayat 1 tentang sistem pendidikan Nasional, yaitu: "Pendidikan adalah usaha sadar dan terencana untuk mewujudkan suasana belajar dan proses pembelajaran agar siswa secara aktif mengembangkan potensi dirinya untuk memiliki kekuatan spiritual keagamaan, pengendalian diri, keperibadian, kecerdasan, akhlak mulia, serta keterampilan yang diperlukan dirinya, masyarakat, Bangsa dan Negara".

Keberhasilan proses pembelajaran tidak terlepas dari kemampuan guru mengembangkan model-model pembelajaran yang berorientasi pada peningkatan intensitas keterlibatan siswa secara efektif didalam proses pembelajaran. Sebagai salah satu komponen dalam proses pembelajaran, model pembelajaran mempunyai peran yang sangat penting karena model pembelajaran merupakan sebuah konsep yang menjadi landasan dalam merancang dan melaksanakan setiap langkah yang ada dalam proses pembelajaran. Kesalahan dalam memilih model pembelajaran akan berakibat fatal pada hasil pembelajaran secara keseluruhan, seperti tidak tercapainya standar kompetensi yang telah ditentukan dalam sistem pendidikan nasional, kurangnya keterlibatan siswa dalam proses pembelajaran dan terdapatnya banyak siswa yang tidak mencapai nilai KKM (Kriteria Ketuntasan Minimal) yang telah ditentukan.

Berdasarkan observasi awal peneliti di SMK Negeri 1 Waingapu ditemukan permasalahan pada pembelajaran matematika, seperti : persentase ketuntasan hasil belajar matematika siswa masih rendah. Hal ini dilihat dari nilai tes formatif Standar Kompetensi Bilangan Real dan bentuk Aljabar yang diajarkan pada semester ganjil tahun pelajaran 2018/2019dimana dari 32 siswa terdapat 18 orang yang tidak mencapai nilai ketuntasan minimal. Rendahnya persentasi hasil belajar matematika siswa di SMK Negeri 1 Waingapu di sebabkan oleh beberapa faktor antara lain: kurangnya motivasi siswa dalam mengikuti pembelajaran matematika, kurangnya kreatifitas siswa dalam memahami materi pelajaran matematika sehingga pemahaman konsep matematika sulit dipahami dan siswa jarang mengajukan pertanyaan kepada guru berkaitan dengan materi yang belum mereka pahami.

Kebanyakan siswa bekerja kurang sistematis dan kurang memperhatikan langkahlangkah penyelesaiannya, mereka hanya mementingkan hasil akhir jawaban sehingga banyak langkah-langkah yang tidak ditempuh. Meskipun berbagai tindakan yang dilakukan oleh guru dalam meningkatkan hasil belajar matematika siswa seperti penggunaan model pembelajaran, materi ajar yang telah disediakan dan media pembelajaran namun hasil belajar matematika siswa masih rendah. Kesimpulannya gaya belajar siswa masih berpusat pada guru dan buku pelajaran. Maka diperlukan suatu model pembelajaran yang dapat meningkatkan keterlibatan siswa secara aktif dalam kegiatan pembelajaran untuk menemukan atau menerapkan sendiri ideidenya. Salah satu solusi bagi guru dalam memilih model pembelajaran yang tepat untuk menciptakan pembelajaran efektif yaitu dengan menerapkan model pembelajaran Discovery Learning.

Discovery Learning adalah proses belajar yang didalamnya tidak disajikan suatu konsep dalam bentuk jadi (final), tetapi siswa dituntut untuk mengorganisasikan sendiri cara belajarnya dalam menemukan konsep (Muhamad, 2016 : 12). Dalam pembelajaran Discovery kegiatan atau pembelajaran dirancang sedemikian rupa sehingga siswa dapat menemukan konsep-konsep dan prinsipprinsip melalui proses mentalnya sendiri. Dalam menemukan konsep, siswa melakukan pengamatan, menggolongkan, membuat dugaan, menjelaskan, menarik kesimpulan dan sebagainya untuk menemukan beberapa konsep dan prinsip (Azhari, 2015 : 15).

Hosnan (Delfita dkk, 2016:5) menyatakan bahwa penerapan model pembelajaran Discovery Learning membuat siswa mengerti konsep dasar dan ide-ide lebih baik serta siswa dapat mentransfer pengetahuannya keberbagai konteks. Sejalan 
dengan pendapat Hosnan \& Bruner (Delfita dkk, 2016:5) menyatakan pengetahuan diperoleh dengan belajar penemuan menghasilkan pengetahuan yang benar-benar bermakna sehingga dapat memberikan hasil belajar penemuan yang mempunyai efek transfer yang lebih baik dari pada hasil belajar lainnya. Penerapan model pembelajaran Discovery Learning yang mengarahkan siswa akif untuk memperoleh pengetahuan sehingga materi pelajaran mengendap dalam pemikiran siswa, pengetahuan yang diperoleh bermakna, membuat peserta didik mengerti konsep dasar dan ide-ide lebih baik serta mempunyai efek transfer yang lebih baik daripada hasil belajar lainnya.

\section{METODE PENELITIAN}

Jenis penelitian ini adalah Penelitian Tindakan Kelas (PTK) kolaboratif dimana peneliti dengan siswa sebagai subyek penelitian, guru sebagai pengamat (observer), dan kepala sekolah sebagai mitra peneliti. Penelitian ini dilakukan untuk mengetahui masalah-masalah atau kendala-kendala yang dialami siswa yang ada di dalam kelas dan berusaha memperbaikinya dengan menerapkan model pembelajaran Discovery Learning untuk meningkatkan hasil belajar materi operasi bentuk aljabar pada siswa kelas X Akuntansi-2 SMK Negeri I Waingapu tahun pelajaran 2019/2020. Penelitian Tindakan Kelas (PTK) ini dilaksanakan pada Agutus 2019, selama 2 bulan. Subjek dari penelitian tindakan kelas ini adalah siswa kelas X SMK Negeri I Waingapu, tahun pelajaran 2018/2019 dengan jumlah siswa 32 orang yang terdiri dari 22 siswa perempuan dan 10 siswa laki-laki. Objek penelitian adalah permasalahan yang diteliti dengan menggunakan model pembelajaran Discovery Learning untuk meningkatkan hasil belajar materi operasi bentuk aljabar.

Penelitian Tindakan Kelas (PTK) ini dilaksanakan dengan melibatkan partisipatif dan kerja sama siswa sebagai subjek penelitian, kepala sekolah sebagai mitra peneliti dan rekan guru mata pelajaran matematika lainnya sebagai pengamat aktivitas siswa dan peneliti. Penelitian Tindakan Kelas (PTK) ini dilakukan melalui dua siklus terdiri dari perencanaan tindakan pelaksanaan tindakan, pengamatan dan refleksi.Teknik pengumpulan data yang digunakan adalah observasi, tes dan dokumentasi. Dalam melaksanakan penelitian tindakan kelas (PTK) instrumen - instrumen sangat diperlukan untuk membantu peneliti mengumpulkan data. Instrumen yang digunakan dalam penelitian ini yaitu:

\section{Lembar Observasi}

Pada lembar observasi atau pengamatan disajikan pedoman observasi yang memuat indikator - indiator yang diamati. Berikut ini adalah pedoman observasi untuk mengamati aktivitas keterlakanaan pembelajaran oleh guru dan aktivitas belajar oleh siswa (Num, 2018 : 41). Pedoman tersebut disajikan pada Tabel 1 dan Tabel 2 berikut ini:

Tabel 1. Indikator Aktivitas Guru

\begin{tabular}{|c|c|}
\hline Tahap & Indikator \\
\hline Pendahuluan & $\begin{array}{l}\text { Memotivasi siswa dan menyampaikan } \\
\text { tujuan pembelajaran }\end{array}$ \\
\hline $\begin{array}{l}\text { Kegiatan } \\
\text { inti }\end{array}$ & $\begin{array}{l}\text { a. Guru memberikan masalah yang } \\
\text { berkaitan dengan materi operasi } \\
\text { bentuk aljabar }\end{array}$ \\
\hline & $\begin{array}{l}\text { b. Membimbing siswa dalam } \\
\text { diskusi kelompok }\end{array}$ \\
\hline $\begin{array}{l}\text { Kegiatan } \\
\text { penutup }\end{array}$ & $\begin{array}{l}\text { a. Membimbing siswa } \\
\text { menyimpulkan pembelajaran }\end{array}$ \\
\hline & $\begin{array}{l}\text { b. Memberikan umpan balik dan } \\
\text { evaluasi }\end{array}$ \\
\hline
\end{tabular}

Sumber : Num (2018 : 41)

Tabel 2. Indikator Aktivitas Belajar Siswa

\begin{tabular}{|c|c|}
\hline Tahap & Indikator \\
\hline Pendahuluan & $\begin{array}{l}\text { a. Mempersiapkan diri mengikuti } \\
\text { pembelajaran } \\
\text { b.Menjawab pertanyaan guru pada awal } \\
\text { pembelajaran } \\
\text { c. Menjawab pertanyaan guru berkaitan } \\
\text { dengan pengetahuan dasar tentang } \\
\text { operasi bentuk aljabar }\end{array}$ \\
\hline $\begin{array}{l}\text { Kegiatan } \\
\text { inti }\end{array}$ & $\begin{array}{l}\text { a.Memperhatikan penjelasan guru } \\
\text { b.Bekerja sama dengan kelompok } \\
\text { c. Mempresentasikan hasil kegiatan } \\
\text { kelompok } \\
\text { d.Menjawab dan mengajukan } \\
\text { pertanyaan }\end{array}$ \\
\hline $\begin{array}{l}\text { Kegiatan } \\
\text { penutup }\end{array}$ & $\begin{array}{l}\text { a.Menyimpulkan pembelajaran } \\
\text { b.Merefleksikan pembelajaran. }\end{array}$ \\
\hline
\end{tabular}

Sumber : Num (2018 : 41)

2. Tes Hasil Belajar (THB)

Tes hasil belajar (THB) diberikan setelah dilakukanya kegiatan belajar mengajar dengan menerapkan model pembelajaran Discovery Learning. 


\section{HASIL DAN PEMBAHASAN}

\section{A. Hasil Penelitian}

\section{Deskripsi Awal Subjek Penelitian}

Siswa memiliki beragam latar belakang sehingga berimplikasi pada kemampuan akademik yang beragam pula. Khususnya pada pelajaran matematika, daya atau kemampuan siswa masih rendah. Terdapat beberapa siswa yang memperoleh nilai baik, namun sebagian besar masih dibawah KKM.

Sebelum melakukan Penelitian Tindakan Kelas (PTK), peneliti terlebih dahulu memberikan tes awal kepada siswa tentang operasi bentuk aljabar. Hasil tes awal pada indikator menetukan operasi hitung pada bentuk aljabar memperlihatkan masih rendahnya hasil belajar siswa. Secara klasikal presentasi ketuntasan yang diperoleh sebesar $31 \%$ atau terdapat 10 orang yang mencapai standar ketuntasan minimal dan 22 orang yang tidak mencapai standar ketuntasan minimal. Terjadi penurunan $13 \%$ dari persentasi ketuntasan klasikal pada hasil ujian mid semester I. Hal ini menunjukan bahwa pengetahuan siswa tentang operasi bentuk aljabar masih rendah.

\section{Sajian Hasil Penelitian Siklus I \\ a. Perencanaan}

Kegiatan peneliti pada tahap ini adalah mempersiapkan hal-hal yang berkaitan dengan tindakan penelitian, seperti : menyusun perangkat pembelajaran siklus I, berkonsultasi dengan guru mata pelajaran matematika yang berperan sebagai mitra tentang perangkat pembelajaran, menyerahkan lembaran observasi dan perangkat pembelajaran pada observer dan menyususn jadwal pelaksanaan penelitian siklus I bersama observer dan mitra.

\section{b. Pelaksanaan}

Pelaksanaan penelitian siklus I yakni 2 kali pertemuan, dimana setiap pertemuan dilaksanakan selama 2 jam pelajaran. Hasil tes untuk mengevaluasi kegiatan pada siklus I yang dibuat dalam bentuk Tes Hasil Belajar (THB). Dari hasil tes diperoleh ketuntasan hasil belajar siswa secara klasikal sebesar 69\% dan rata-rata kelas 76,25 terdapat 22 siswa yang mencapai Kriteria Ketuntasan Minimal (KKM).
Hal ini menunjukan bahwa adanya peningkatan dibandingkan hasil pada tes awal. Ketuntasan klasikal pada tes awal sebesar $31 \%$ sedangkan ketuntasan klasikal siklus I sebesar 69\%. Hal ini menunjukan bahwa penerapan model pembelajaran discovery learning pada pembelajaran matematika dapat meningkatkan hasil belajar siswa, walaupun belum mencapai target yang diinginkan. Oleh karena itu, untuk mencapai standard ketuntasan klasikal minimal perlu dilakukan perbaikan melalui siklus II.

\section{c. Tahap Pengamatan}

Kegiatan pengamatan dilakukan oleh teman sejawat selama kegiatan pembelajaran berlangsung, baik terhadap aktivitas siswa maupun aktivitas guru. Pengamatan diukur menggunakan lembar observasi.

Hasil pengamatan yang dilakukan pada siklus I secara lengkap disajikan pada lembar observasi aktivitas guru. Dari analisis hasil observasi aktivitas guru diperoleh persentase rata-rata sebesar $83 \%$ dengan kriteria baik. Dari hasil analisis observasi tersebut menjelaskan bahwa guru melaksanakan pembelajaran belum maksimal. Oleh karena itu, diperlukan perbaikan pada siklus berikutnya.

Pengamatan terhadap aktivitas siswa dilakukan selama kegiatan pembelajaran berlangsung oleh guru dan observer. Hasil pengamatan aktivitas siklus I disajikan pada lembar observasi aktivitas siswa. Dari analisis hasil observasi aktivitas siswa pada siklus I diperoleh persentase rata-rata sebesar $72 \%$ dengan kriteria baik. Hal ini menjelaskan bahwa aktivitas siswa dalam proses pembelajaran pada siklus I masih belum efektif, namun adanya perubahan positif pada siswa. Oleh karena itu, diperlukan penyempurnaan atau perbaikan pada siklus berikutnya.

\section{d. Tahap Refleksi}

Pada tahap ini kegiatan dilakukan dengan mengkaji ulang proses pembelajaran yang dilakukan pada siklus I. dalam refleksi peneliti melibatkan observer untuk memberi saran atau usulan mengenai proses kegiatan pembelajaran pada siklus I.

Dari analisis hasil pekerjaan siswa pada tes siklus I diperoleh penilaian terhadap hasil tes yang akan menjadi acuan bagi peneliti 
dalam menetukan tindakan selajutnya. Penilaian-penilaian tersebut sebagai berikut:

a) Hasil tes pada siklus I diperoleh persentase ketuntasan klasikal sebesar $69 \%$ dengan rata-rata kelas 76,25 . Hal ini menjelaskan bahwa secara klasikal siswa belum tuntas karena belum mencapai ketuntasan klasikal minimum yaitu .

b) Persentasi keterlaksanaan pembelajaran oleh guru pada siklus I mencapai $75 \%$ dengan kategori baik. Hal ini menunjukan bahwa pelaksanaan pembelajaran oleh guru belum dilakukan secara maksimal dan masih membutuhkan perbaikan.

c) Persentasi keterlaksanaan pembelajaran oleh siswa pada siklus I mencapai $72 \%$ dengan kategori baik. Hal ini berarti belum memenuhi indikator keberhasilan yang telah ditetapkan maka perlu adanya perbaikan.

Berdasarkan hasil observasi peneliti dan observer terhadap aktivitas siswa dan guru dalam pelaksanaan pembelajaran pada siklus I ditemukan kendala-kendala seperti:

1) Guru dan siswa belum melaksanakan pembelajaran dengan baik.

2) Interaksi antara guru dan siswa masih kurang.

3) Sebagian siswa pasif dalam diskusi kelompok

4) Siswa masih takut untuk bertanya kepada guru berkaitan dengan materi yang belum mereka pahami.

5) Kemampuan guru untuk merangsang keaktifan siswa pada proses pembelajaran masih kurang.

6) Kurangnya efisiensi (ketepatan waktu) dalam penggunaan waktu pada tahap-tahap pembelajaran yang sesuai RPP.

Dari temuan-temuan diatas, dijadikan sebagai bahan pertimbangan atau acuan bagi peneliti dalam melaksanakan pembelajaran pada siklus II. Oleh karena itu perlu dilakukan perbaikan terhadap kendala-kendala yang ditemukan itu. Hal-hal yang perlu diperbaiki yaitu:

1) Guru merevisi RPP untuk mengoptimalkan proses pembelajaran pada siklus II
2) Guru perlu meningkatkan motivasi siswa agar mereka bisa menanyakan hal-hal yang belum mereka pahami tanpa adanya rasa takut atau malu serta memberikan reward kepada siswa yang bertanya.

3) Guru harus membimbing siswa secara menyeluruh dalam kegiatan kelompok.

Berdasarkan uraian-uraian diatas, dapat disimpulkan bahwa kegiatan pembelajaran pada siklus I belum mencapai mencapai standar keberhasilan yang ditetapkan. Oleh karena itu, perlu adanya tindakan lanjutan pada siklus II.

\section{Sajian Hasil Penelitian Siklus II}

Berdasarkan refleksi pada siklus I, peneliti melakukan perencanaan untuk memperbaiki hal-hal yang belum terlaksana pada siklus I guna penyempurnaan proses pembelajaran di kelas. Pelaksanaan penelitian siklus II masih sama dengan siklus I yaitu melalui tahap perencanaan, pelaksanaan, observasi dan refleksi.

\section{a. Tahap Perencanaan}

Pada tahap ini, peneliti menyusun rencana pelaksanaan pembelajaran, menyiapkan lembar observasi aktivitas siswa dan guru; menyiapkan lembar validasi perangkat pembelajaran,menyiapkan materi pembelajaran dan menyiapkan pembagian kelompok secara heterogen.

\section{b. Tahap Pelaksanaan}

Pada tahap ini pelaksanaan penelitian dilakukan dua kali pertemuan, dimana setiap pertemuan dilaksanakan selama 2 jam pelajaran. Hasil tes siklus II menunjukkan hasil belajar siswa secara klasikal sebesar 94\% dan rata-rata 90,9375. Hal ini menunjukan bahwa adanya peningkatan yang sangat baik dari hasil tes siklus I maupun hasil tes awal.

Persentase ketuntasan yang diperoleh pada siklus II sudah melampau standar ketuntasan klasikal minimal artinya penerapan model pembelajaran discovery learning pada pembelajaran matematika dapat meningkatkan hasil belajar siswa. Oleh karena itu, penerapan model pembelajaran discovery learning pada materi operasi bentuk aljabar adalah salah satu solusi yang tepat untuk masalah yang dihadapi siswa. 


\section{c. Tahap Pengamatan}

Pengamatan selama proses pembelajaran berlangsung. Pengamatan diukur menggunakan lembar observasi baik observasi terhadap guru maupun observasi terhadap siswa. Keterlaksanaan proses pembelajaran diamati oleh observer. Hasil analisis observasi aktivitas guru pada siklus II diperoleh persentase rata-rata sebesar $98 \%$ dengan kriteria sangat baik. Sedangkan hasil analisis hasil observasi aktivitas siswa pada siklus II diperoleh persentase rata-tata sebesar $92 \%$ dengan kriteria sangat baik.

\section{d. Tahap Refleksi}

Pada tahap ini guru mengkaji kembali proses pelaksanaan tindakan pada siklus II. Dalam tahap refleksi guru melibatkan observer untuk memberikan usul atau saran berkaitan dengan pelaksanaan pembelajaran pada siklus II. Hasil pekerjaan siswa pada tes siklus II dianalisis sedemikian rupa sehingga nilai yang diperoleh akan menjadi acuan bagi peneliti dalam menentukan tindakan selanjutnya. Penilaian-penilaian tersebut adalah:

a. Berdasarkan hasil tes siklus II diperoleh persentase ketuntasan klasikal sebesar 94\% dan rata-rata kelas 90,9375. Hal ini menjelaskan bahwa secara klasikal siswa sudah tuntas karena sudah mencapai ketuntasan klasikal yaitu $\geq 85$.

b. Pada siklus II persentase keterlaksanaan pembelajaran oleh guru mencapai $98 \%$ dengan kategori sangat baik. Hal ini menunjukan bahwa pelaksanaan pembelajaran oleh guru sudah maksimal dan sudah memenuhi indicator keberhasilan yang telah ditetapkan.

c. Persentase keterlaksanaan pembelajaran oleh siswa pada siklus II mencapai $92 \%$ dengan kategori sangat baik. Dengan ini sudah memenuhi indikator yang telah ditetapkan.

Berdasarkan uraian diatas, dapat simpulkan bahwa pembelajaran pada siklus II sudah mencapai standar keberhasilan yang ditetapkan sehingga penelitian ini tidak perlu dilanjutkan.

\section{B. Pembahasan Hasil Penelitian}

Berdasarkan hasil pengamatan peneliti selama pelaksanaan pembelajaran siklus I dan siklus II temukan adanya peningkatan pada hasil belajar siswa dan keterlaksanaan pembelajaran oleh siswa dan guru. Hal ini dilihat dari siswa yang aktif, antusias dan bertanggung jawab dalam selurus proses pebelajaran.

1. Prestasi Belajar Siswa

Prestasi belajar siswa diperoleh dari hasil tes siklus I dan siklus II. Hasil tes tersebut menunjukan adanya peningkatan seperti pada Tabel berikut ini.

Tabel 3. Persentase Peningkatan Hasil Belajar Siswa Siklus I dan Siklus II

\begin{tabular}{|c|c|c|c|c|c|}
\hline $\begin{array}{c}\text { Nilai } \\
\text { Siswa }\end{array}$ & Kategori & $\begin{array}{c}\text { Siklus } \\
\text { I }\end{array}$ & $\%$ & $\begin{array}{c}\text { Siklus } \\
\text { II }\end{array}$ & $\%$ \\
\hline $\begin{array}{c}75 \leq n \geq \\
100\end{array}$ & Tuntas & 22 & 69 & 30 & 94 \\
\hline $75<\mathrm{n} \geq 0$ & Tidak tuntas & 10 & 31 & 2 & 6 \\
\hline
\end{tabular}

\section{Kegiatan Pembelajaran Oleh Guru}

Kegiatan observasi terhadap aktivitas guru dalam proses pembelajaran dilakukan oleh observer yang berpedoman pada lembar observasi aktivitas guru siklus I dan lembar observasi aktivitas guru siklus II. Hasil observasi tersebut menunjukan adanya peningkatan dalam pembelajaran, seperti yang tertera pada tabel berikut ini.

Tabel 4. Persentase Peningkatan Aktivitas Guru Siklus I dan Siklus II

\begin{tabular}{cccccc}
\hline $\begin{array}{c}\text { Pelaksana } \\
\text { an }\end{array}$ & $\begin{array}{c}\text { Siklu } \\
\text { s I }\end{array}$ & $\begin{array}{c}\text { Krite } \\
\text { ria }\end{array}$ & $\begin{array}{c}\text { Siklus } \\
\text { II }\end{array}$ & $\begin{array}{c}\text { Krit } \\
\text { eria }\end{array}$ & $\begin{array}{c}\text { Penigkat } \\
\text { an }\end{array}$ \\
\hline $\begin{array}{c}\text { Kegiatan } \\
\text { pembelajar } \\
\text { an }\end{array}$ & $83 \%$ & Baik & $98 \%$ & $\begin{array}{c}\text { Sang } \\
\text { at } \\
\text { baik }\end{array}$ & $15 \%$ \\
\hline
\end{tabular}

\section{Kegiatan Pembelajaran Oleh Siswa}

Kegiatan observasi terhadap aktivitas siswa dalam proses pembelajaran dilakukan oleh guru dan observer dengan menggunakan lembar observasi aktivitas siswa siklus I dan siklus II. Hasil observasi tersebut menunjukan adanya peningkatan proses pembelajaran seperti yang tertera pada tabel berikut ini.

Tabel 5. Persentase Peningkatan Observasi Aktivitas Siswa Siklus I dan Siklus II

\begin{tabular}{cccccc}
\hline $\begin{array}{c}\text { Pelaksan } \\
\text { aan }\end{array}$ & $\begin{array}{c}\text { Sikl } \\
\text { us I }\end{array}$ & $\begin{array}{c}\text { Kriter } \\
\text { ia }\end{array}$ & $\begin{array}{c}\text { Sikl } \\
\text { us II }\end{array}$ & $\begin{array}{c}\text { Kriter } \\
\text { ia }\end{array}$ & $\begin{array}{c}\text { Penigkat } \\
\text { an }\end{array}$ \\
\hline $\begin{array}{c}\text { Kegiatan } \\
\text { pembelaja } \\
\text { ran }\end{array}$ & $72 \%$ & Baik & $92 \%$ & $\begin{array}{c}\text { Sangat } \\
\text { baik }\end{array}$ & $20 \%$ \\
\hline
\end{tabular}


Berdasarkan hasil penelitian yang telah diuraikan diatas, peneliti menyimpulkan bahwa prestasi belajar matematika kelas $\mathrm{X}$ Akuntansi-2 SMK Negeri I Waingapu mengalami peningkatan dengan menerapkan model pembelajaran discovery learning. Hal ini dilihat dari hasil belajar siswa yang di kaji melalui lembar observasi guru dan siswa dan juga hasil tes siklus I dan siklus II.

Berdasarkan hasil analisis peneliti terhadap hasil observasi aktivitas guru dalam pembelajaran, diperoleh tingkat pelaksanaan aktivitas guru siklus I sebesar $83 \%$ dan siklus II sebesar 98\%. Hal ini menjelaskan bahwa aktivitas guru dalam pembelajaran mengalami peningkatan sebesar $15 \%$ dari siklus I

Berdasarkan hasil analisis peneliti terhadap observasi aktivitas siswa dalam pembelajaran, diperoleh tingkat pelaksanaan aktivitas siswa siklus I sebesar $72 \%$ dan siklus II sebesar 92\%. Hal ini menjelaskan bahwa aktivitas siswa mengalami peningkatan sebesar $20 \%$ dari siklus I.

Peningkatan hasil belajar siswa dilihat dari penilaian hasil belajar pada aspek kognitif siswa dengan membagi skor yang diperoleh dengan skor maksimal dikali dengan 100. Syarat kriteria ketuntasan minimal (KKM) adalah 65 dan ketuntasan klasikal $\geq 75$ (cara hitungnya yaitu jumlah siswa yang tuntas dibagi dengan jumlah siswa yang mengikuti tes di kali $100 \%$ ).

Berdasarkan hasil analisis peneliti terhadap hasil belajar siswa ditemukan adanya peningkatan. Dimana hasil belajar siswa siklus I diperoleh katuntasan klasikal sebesar dan siklus II sebesar. Hal ini menunjukan peningkatan sebesar dari siklus I. Peningkatan ini dihitung dengan mengurangkan nilai ratarata siklus II dan nilai rata-rata siklus I dikali $100 \%$.

\section{SIMPULAN DAN SARAN}

Tujuan utama peneliti melaksanakan penelitian tindakan kelas (PTK) di SMK Negeri I Waingapu yaitu untuk meningkatkan hasil belajar siswa dengan menerapkan model pembelajaran Discovery Learning pada pembelajaran matematika. Hasil penelitian menunjukkan bahwa:

1) Penerapan model pembelajaran discovery learning dapat meningkatkan hasil belajar siswa pada materi operasi bentuk aljabar. Terbukti dari meningkatnya jumlah siswa yang mencapai nilai ketuntasan minimal (KKM). Dimana jumlah siswa yang tuntas pada tes awal sebanyak 10 orang, siklus I sebanyak 22 orang dan siklus II sebanyank 30 orang.

2) Penerapan model pembelajaran learning dapat meningkatkan aktivitas siswa dalam mengikuti pembelajaran matematika. Siswa merasa senang, aktif dan bersemangat dalam mengikuti pembelajaran matematika.

Beberapa saran yang diajukan penulis dalam penelitian ini yaitu:

1. Bagi guru mata pelajaran matematika kelas $\mathrm{X}$, agar hendaknya menerapkan model pembelajaran discovery learning pada pembelajaran matematika khususnya materi operasi bentuk aljabar.

2. Dalam penelitian ini penulis hanya terbatas pada aspek kognitif, diharapkan peneliti lain akan meneliti aspek psikomotorik dengan menerapkan model pembelajaran discovery learning.

\section{DAFTAR PUSTAKA}

Azhari. 2015. Penerapan Model Pembelajaran Discovery Learning Terhadap Peningkatan Hasil Belajar Siswa Kelas XI-IPA1 Pada Materi Sistem Pernapasan Di SMA Negeri Unggul Sigli. Jurnal Biologi Edukasi. 1, 13-21.

Delfita, Ovemy, dkk. 2017. Penerapan Model Discovery Learning Untuk Meningkatkan Hasil Belajar Matematika Siswa Kelas X Mia 4 Sma Negeri 5 Pekanbaru.

Muhamad Nurdin. 2016. Pengaruh Metode Discovery Learning Untuk Meningkatkan Representasi Matematis Dan Percaya Diri Siswa. Jurnal Pendidikan Universitas Garut. 1, 9-22.

Num Katarina. (2018). Penerapan Model Pembelajaran Discovery Learning Dalam Materi Trigonometri Pada Siswa Kelas X SMAN 1 Ende Tahun Pelajaran 2017/2018. (Skripsi). Universitas Flores. 